\title{
Appreciation of “A Route of Evanescence”
}

\author{
LYU Juan \\ University of Shanghai for Science and Technology, Shanghai, China
}

\begin{abstract}
The poem is chosen from The Poems of Emily Dickinson. Emily Dickinson observes nature carefully, recording things in the form of poetry. She often describes small things that people tend to overlook. In her poetry, things can be divided into two basic categories: natural beauty, plants and animals. This chosen poem is about a hummingbird, with two stanzas and eight lines in all. Though it is short, it is not easy to understand. What I have done is to appreciate the poem by rhetorical, phonological, lexical, and grammatical means. Being different ways, they all function to serve the poem to reach a harmonious, integrated meaning.
\end{abstract}

Keywords: poem, rhetorical, phonological, lexical means, grammatical means

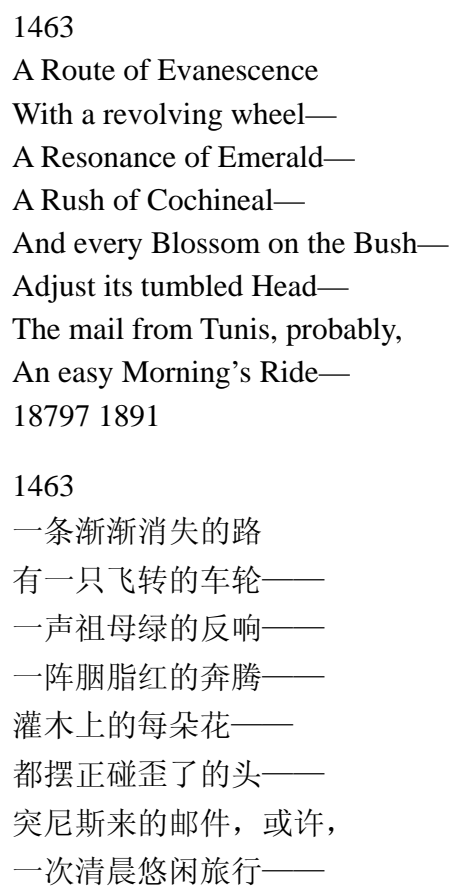

After reading this poem, these words such as “revolving (飞转的), resonance (反响), rush (奔腾), emerald (祖母绿), cochineal (胭脂红)” jump into our minds. All of us are deeply impressed by its colourfulness, the speedy action, and its vibrating sound. However, do you know what it's talking about? There is no protagonist, no event. What exactly does this poem want to show to us?

In fact, the protagonist in this poem is a hummingbird (蜂鸟). A hummingbird is a little bird. It has

LYU Juan, master, researcher, School of Foreign Language, University of Shanghai for Science and Technology, Shanghai, China. 
colourful metal-shining wings, which can reflect various colours in the sunshine. Its beak (喙), as sharp, long as a needle, is used to collect the flower nectar (花蜜). When the bird is flying, its wings vibrate with high-frequency of 50-70 times one minute. The most peculiar feature which distinguishes hummer from other birds is that not only can it fly forward, but also can fly backward in the air. It flies swiftly.

\section{Rhetorical Devices and Implications}

This poem is about a hummingbird. It hovers, its wings are flashing in the sunshine, then it darts away, but the poem is full of metaphors.

"A Route of Evanescence” is the trial of hummingbird's flying. "A revolving wheel” symbolizes the flying wings. When the bird is flying, its wings vibrate with high-frequency of 50-70 times one minute. Hummingbird's wings really revolve, so the second sentence vividly shows the quick movement in the hummingbird's wings and how the bird rushes about. "A Resonance of Emerald” implies the bird's colourfulness and noisy made by its flying. "A Rush of Cochineal” in fact symbolizes the process of collecting nectar. As we know, its beak (嗀), as sharp, long as a needle, is used to collect the flower nectar (花蜜). So cochineal means the flowers.

Blossom is personified as if they were live people who have "tumbled heads" to be "adjusted". As the bird passes the blossom in such a quick rush of cochineal, every blossom on the bush adjusts its tumbled head. "The Mail from Tunis", we can get thousands of imaginations. I would guess "the Mail from Tunis" is something from God or foreign places. It is easy for her because how passionate it is, it is like a qualified and vivacious messenger who can treat a trip as “An easy Morning’s Ride”.

\section{Phonological Devices}

There are various phonological devices we can use for poetic effects. These phonological techniques realize the poetic function of appreciation by three ways: firstly, by providing very regular sound patterns, such as metrical patterns, rhyme schemes and alliteration, etc., by which the reader feels that the sound pattern is smooth. These eight lines rhyme "wheel-cochineal", and "head-ride". "Wheel" in the second line and "Cochineal" in the fourth line belong to "full rhyme"-the same vowel sound preceded and followed by identical consonants. Lines 6 and 8 show slant rhyme, which take the "perfect" rhyme away from the first stanza, as to say the hummingbird caused to scene to be elegant while there, now it's just bland. No distinct rhyme is found between Lines 1 and 3, but "Wheel" and "Cochineal" are a perfect rhyme. This is due to the words "Evanescence" and "Emerald". Lines 1 and 3's meter is iambic tetrameter, and Lines 2 and 4 are iambic tri-meter.

From the first line "A Route of Evanescence" all the way through each line of the first stanza, alliteration of $/ \mathrm{r}$ / occurs. The sound of the "R" words such as "Resonance" and "Rush" causes the reader to "hear" or imagine the quick movement in the hummingbird's wings and how the bird rushes about. Since the subject of the first four lines is the speedy action of a hummingbird, /r/ alliteration undoubtedly implies a noisy and hurry motion. A plenty of consonants rhyme /s/ in "Evanescence, Resonance, Rush, Blossom, its, Tunis, Morning's" give us a feeling of frying smoothly and softly. Two words may also serve as rhymes if they end on the different vowed sound followed by same consonants. Pay attention, "Head" in the sixth line and "Ride" in the eighth line belong to "near rhyme", because head and ride are with same consonant but different vowels. Emily Dickinson knew exactly what she was doing and used this "near-rhyme" with full attention. In this poem, 
compared with full-rhyme, near-rhyme happens to accord with the hummer's action characteristic, leaving us a feeling of dynamic and activeness.

\section{Lexical Features}

1. As a result of the unique function of poetry, the range of choices of words is much larger than that in other genres. As we know, the poet read a large amount of classical works including Bible and plays written by Shakespeare. In this way, poetry keeps its stylistic feature of classicalism and elegance by using these words, such as "Evanescence, Resonance" derived from Latin in this poem. In addition, they are also exotic words.

The speaker in the poem uses exotic words such as "Evanescence”, "Resonance”, and "Cochineal” to grab the reader's attention and illustrate how exotic the hummingbird actually is. The word "revolving" describes the flapping motion of the bird's wings and compares the repetition of the " $\mathrm{R}$ " to the wing movement. The poet uses "mail" that travelled supposedly from "Tunis" in a morning to show how the hummingbird comes and goes, so as to reinforce the mythical features of the common things the images created in the poem; hummingbird, blossom, mail become more and more mythical, as if they are not common things any more, but secret and divine objects. This is exactly what this master of image tries to achieve: finding mythical feelings in common things.

2. Daily vocabulary still forms the most basic part of poetic diction. Even these words, if used appropriately, can be used to achieve excellent artistic effect. Apart from those Latin words mentioned above, all the others are common words, but the artistic conception it creates is fascinating: Word like blossom is personified as if they were live people who have "tumbled heads" to be "adjusted". The speaker accuses the flower of adjusting its "Head" when in actuality flowers do not have heads. Words like "wheel”, "rush" are taken together; it forms a dynamic and fast-moving picture.

3. Words of different fields or sets are used together to form an organic whole to express their profound implications and create aesthetic values. There are two sets of words intersecting with each other. They are; first, colour set: emerald, cochineal; second, action set: resonance, rush. So in poetic language, words of any fields can be selected to achieve the intended effects. Here, the most original device is that the poet uses colour images to describe the actions. The coexistence of colours, sounds, actions aims to present a precipitate, abrupt actions, vibrating sounds, and glaring colours, leaving us a whole impression of instant vanishment and emergence.

4. Grammatical features: One feature of Dickinson's poems is the frequent use of dash. Looking at the form of this poem, we can also easily find the unique usage of dash replacing comma, which means a stop or a pause. Within eight lines are five striking dashes, which are in consistency with the theme of the poem, when reading the poem, the distinctive usage of dash vividly depicts the intermittence of hummer's flying. If we change the dash into the commas, the conceptual meaning remains the same, but its artistic value is greatly reduced. Here, “Revolving”, “Resonance”, "Rush”, “Adjust” are words describing lightning motions; they are intermittent, not stops or pauses.

In this poem, except for "mail”, all the norms are capitalized. Maybe the poet wants to highlight the visual effects by capitalized words. This poem is of two stanzas and eight lines in all. Though it is short, it is not easy to understand. What I have done is to appreciate the poem by rhetorical, phonological, lexical, and grammatical means. 


\section{References}

Johnson, T. H. (1955). The poems of Emily Dickinson, Vol. 3. Cambridge Mass: Harvard University Press.

Pu, L., \& Liu, X. H. (2000). 艾米莉狄金森: 一个谜. 兰州大学学报（社科版）, 28(5), 151-156.

Xu, Y. Z. (2005). 英语文体学教程. 北京: 高等教育出版社.

Zhang, D. L. (2008). 英语文体学教程. 北京: 高等教育出版社. 